\title{
TILLYKKE TIL REDAKTØREN
}

Den 29. januar 2007 fyldte Britta Kyvsgaard 60 år. Britta har været redaktør for dette tidsskrift siden 1999 og fortjener - om nogen - en hyldest på den nordiske kriminologiske scene. Ikke alene bidrager Britta igennem sin egen forskning konstant med ny kriminologisk viden, frembragt med den sande forskers omhu. Men hun har også viet hele sit faglige - og store dele af sit private - liv til kriminologien, først og fremmest den nordiske. Britta blev dansk kontaktsekretær for NSfK i sine unge dage og har siden arbejdet som rådsmedlem i flere perioder. For tiden lægger hun sin indsats i såvel redaktørposten for tidsskriftet som rådsarbejdet.

Brittas kriminologiske karriere startede som så mange andres med at hun måtte "springe fra sten til sten" for at tjene til dagen og vejen ved at flette denne ene projektbevilling sammen med den næste. Den erfaring har sandsynligvis bidraget til det store og utrættelige engagement, Britta i dag udviser for yngre forskere. Det gælder både engagementet $\mathrm{i}$ at levere solid forskning, og i at overleve mens man gør det. Britta evner som få at forene en høj faglig kompetence med en stærk personlig integritet. Måske er det meget væsentligt for at forstå, hvordan hun i det daglige mestrer to funktioner, som hver især kræver hele mennesket, nemlig at være aktiv og uhildet forsker og at være loyal embedsperson.

Forskerens grundighed er et medfødt personlighedstræk hos Britta. Absolut intet overlades til tilfældighederne. Sådan er det også med dette tidsskrift. Havde der været blot en flig af plads til "assistenternes" manipulation, var hele dette nummer blevet et særnummer af "festskrift-karakter". Det havde været passende! Men intet slipper forbi redaktørens skarpe blik. Derfor må hun nøjes med denne korte gratulation, smuglet ind efter 2. korrekturen.

Britta søger aldrig selv at komme i rampelyset. Stod det til hende, ofrede hun gerne endnu mere tid på jagt efter den sandhed, de store registre og mange statistikker rummer. Der er ofte bud efter hende, både i europæisk og international kriminologisk sammenhæng, og Britta er i sandhed en værdig ambassadør for vores nordiske kriminologi.

Sammen med tidsskriftets læsere ønsker vi redaktøren et stort tillykke!

Susanne Clausen, Annalise Kongstad, Anette Storgaard

Tak til Paul Larsson som lod sin anmeldelse af Jesper Ryberg: Retsfølelsen $u d g a ̊$ for at gøre plads til at bringe ovenstående. Anmeldelsen vil blive bragt i naeste nummer af NTfK. 